\title{
The Rise of China and the Black Sea Region: Opportunities and Challenges for NATO
}

\section{Deborah Sanders}

China's rising power is one of the most significant global geostrategic developments of the $21^{\text {st }}$ century and will have a profound effect on NATO members and partners in the Black Sea Region (BSR). ${ }^{1}$ Jens Stoltenberg, the NATO Secretary General, put China firmly on NATO's radar when he recently stated that the alliance must face up to Beijing's growing military might and ambitions. Recent Chinese activities, including working more closely with Russia, increasing its investment in critical infrastructure (such as ports), and Beijing's use of COVID-19 disinformation campaigns, he has argued, all have security consequences for NATO that cannot be ignored. ${ }^{2}$ Over the last year, there has been a growing recognition within NATO that the rise of China has been of such a scale and at such proximity to core NATO interests that no member or part of NATO can afford to sidestep or ignore it.

This is especially so in the BSR. ${ }^{3}$ Under the Belt and Road Initiative (BRI), China has significantly increased its engagement with and investments in the Black Sea and as a result has expanded its influence there, becoming an important player in the region. ${ }^{4}$ This increase in Chinese engagement in the region will inevitably affect maritime security and stability. Given that the Black Sea is home to three NATO members, Bulgaria, Romania and Turkey, and two NATO partners, Georgia and Ukraine, China's growing presence in the region will affect Allied Maritime Strategy (AMS) in the future.

The London Declaration, which emerged from the NATO summit in 2019, recognised China's growing influence and that this presented 'both

1 The BSR is taken in this article to comprise the six littoral states of the Black Sea.

2 Alexandra Brzozowski, 'China 'not an enemy' but NATO must face growing role, NATO chief says', Euractiv, 8 June 2020.

3 Jens Ringsmore and Sten Rynnnig, 'China brought NATO closer together', War on the Rocks, 5 February 2020.

4 Bruno Maçães, Belt and Road, A Chinese World Order, (C. Hurst \& Co, 2018). 
opportunities and challenges' that the alliance needed to address. ${ }^{5}$ This chapter examines those opportunities and challenges and argues that the AMS will need to reflect the fact that, while China's increasing engagement will create potential maritime security challenges for NATO members and partners, it could also lead to new opportunities for stability and maritime cooperation. In making this argument, this chapter is divided into three parts. The first part explores China's growing influence in the BSR and illustrates the degree of variation in the levels of engagement with the BRI amongst Black Sea littoral states. The second section looks at how Chinese influence is likely to increase further in the BSR due to the opening of the new Istanbul Canal and the increase in global containerised shipping. The last section considers the opportunities and challenges for NATO offered and posed by China's increasing engagement in the BSR, especially in terms of the development of the AMS.

\section{China and the BSR}

Over the last few years, China has significantly increased its engagement and investments in the BSR. The key context for this is the BRI, a multifaceted global investment programme. The BRI has both continental and maritime dimensions and is focused on increasing integration and connectivity through such activities as reducing trade barriers, increasing financial and infrastructure investments, and promoting the coordination of policy. Though its key features are financial and economic, its purpose and ramifications, of course, are also political and strategic, since the BRI is also a conduit for Chinese interests and influence. In the Black Sea, China has focused primarily on infrastructure and port development projects in order to turn the region into a transportation and logistics hub linking Asia to Europe. ${ }^{6}$ The level of engagement with China by BSR littoral states varies enormously: from little to no investment in Romania, which has instead favoured cooperation with Washington and Brussels over Beijing, to more active engagement and cultivation by Georgia, Ukraine and Bulgaria. More recently, Turkey has also tilted increasingly towards Beijing. Of all the Black Sea littoral states, Georgia has been the most active in securing

5 Christopher Woody, 'NATO is finally talking about China and there are 3 big problems it has to address', Business Insider India, 5 December 2019.

6 Revaz Topuria, 'Georgia can still be a hub for China, but only if the Belt and Road Survives', The Diplomat, 27 August 2019. 
Chinese investment and this looks set to continue in light of its desire to mitigate some of the damaging effect of the COVID-19 pandemic on the Georgian economy. ${ }^{7}$ Georgia is seen by China as an important transportation and logistics hub linking Asia to Europe via the BRI. ${ }^{8}$ As part of its commitment to becoming a regional hub for trade, the Georgian government has developed ambitious plans to develop its maritime infrastructure along its Black Sea coastline; making Georgia's ports an integral part of China's BRI. ${ }^{9}$ As a result, Tbilisi is looking to expand its largest port, Poti, where China already has important interests, and to build a new deep-sea water port in Anaklia. Under an ambitious two-stage expansion plan, Poti port, which is a major seaport off the eastern Black Sea coast, will be modernised and upgraded. ${ }^{10}$ During an official visit to Georgia in May 2019, China's foreign minister announced that the two countries would also explore further avenues of bilateral cooperation. ${ }^{11}$ In a significant sign of China's commitment to Georgia, the Asian Infrastructure Development Bank (AIIB) loaned Georgia just under $\$ 100$ million in May 2020 for COVID-19 relief. ${ }^{12}$

Despite getting off to a slower start, China's interest in Ukraine has also increased significantly over the last few years. ${ }^{13}$ For Ukraine, the BRI is seen as a tool with which to improve infrastructure, attract foreign investment, and as an important means of reducing its dependence on Russian markets. Sino-Ukrainian bilateral trade relations have increased dramatically, and China is now Ukraine's largest single national trading partner, pushing Russia into second place. ${ }^{14}$ For China, Ukraine's ports and infrastructure give Beijing access to agricultural products. In 2015, China's Oil

7 'IMF seeks Georgia's economy contracting by 5\% in 2020', Reuters, 16 September 2020.

8 Revaz Topuria, 'Georgia: The Key to China's 'Belt and Road', The Diplomat, 28 April 2016; Joseph Larsen, 'Georgia: The Black Sea Hub for China's 'Belt and Road', The Diplomat. 3 May 2017.

9 John C. K. Daly, 'China and Georgia Deepen Transit Cooperation', Eurasian Daily Monitor, 15/63, 23 April 2018.

10 'APM Terminals unveils expansion project for Georgia's Poti Sea Port', SAFETY4SEA, 5 February 2020.

11 Emil Avdaliani, 'China set to increase its influence in Georgia', Georgia Today, 30 May 2019.

12 'AIIB allocates $\$ 100$ million fund to Georgia for COVID-19', Belt and Road News, 23 May 2020.

13 Sergiy Gerasymchuk and Yurri Potitta, 'Ukraine-China after 2014: a new chapter in the relationship', Friedrich Ebert Stiftung, Kyiv, 26 September 2018.

14 Natalia Datskevych, 'It's official: China is Ukraine's largest trading partner', Kyiv Post, 27 September 2019. 
and Food Corporation (COFCO) bought Noble Agri Resources, an international agricultural corporation with assets in Ukraine, and a year later it also opened a grain terminal in the port of Mykolaiv in Ukraine. COFCO has also recently signed a Memorandum of Understanding to develop port infrastructure in Mariupol on the Sea of Azov in Ukraine. ${ }^{15}$ As part of this attempt to increase Ukraine's utility as a hub for agriculture, China's Harbor Engineering Company (CHEC) has also completed the first stage of the renovation of the Ukrainian Black Sea port of Yuzhny in Odessa and awarded a contract for the port of Chornomorsk. ${ }^{16}$

For the Chinese government, Bulgaria is also recognised as a useful logistics and transportation hub into Europe, giving Beijing direct access to the EU single market. In 2016 China agreed to develop the Bulgarian Black Sea port of Burgas as a logistics hub for trading in goods with partners in Central and Eastern Europe. ${ }^{17}$ More recently, in 2019 the China Machinery Engineering Corporation signed a USD 120 million contract with the Joint stock company Logistical Center-Varna for the joint development of port infrastructure in Varna. The project will make Varna the first modern port in Bulgaria equipped with up-to-date warehouse facilities and it will also greatly improve Sofia's cargo handling capacity. ${ }^{18}$ The Bulgarian government is also keen to improve its infrastructure, including transport and communication systems and logistic facilities, in order that Beijing is able to fully utilise Sofia's geographical advantages. ${ }^{19}$ To address these challenges and encourage Chinese investment, Bulgaria has also signed a framework deal with China to build a range of transport infrastructure, including four motorways and a tunnel under the Balkan Mountains. ${ }^{20}$

Although both Turkish trade with China and Chinese investment in Turkey remain low, the Turkish government has increasingly sought closer economic ties with China, particularly in light of its strained relations with the US and Europe. Concern at the rollback of democracy in Turkey, for

15 Alexander Query, 'China to invest over \$50m in port city of Mariupol', Kyiv Post. 29 October 2019.

16 'Chinese company signs deal to upgrade Ukraine's Black Sea ports', Xinhua, 7 April 2018.

17 'China to Invest EUR $20 \mathrm{M}$ in Bulgaria's Burgas Port to Facilitate Trade with Europe', Novinite.com. 6 May 2016.

18 'China secures Bulgaria foothold', Port Strategy, 18 April 2019.

19 'Interview: Belt and Road Initiative could put Bulgaria on global logistics map: expert', Xinhua, 27 June 2018.

20 'Bulgaria agrees four-motorway deal with government of China', Global Construction Review, 9 July 2018. 
example, and the refusal of the US to hand over the Turkish cleric Fethullah Gulen for allegedly instigating the 2016 Turkish coup, have created a growing chasm between Washington and Ankara. ${ }^{21}$ Diverging policies and perspectives over Syria, Libya and energy exploration near Cyprus as well as the Turkish decision to purchase an advanced air defence system from Russia have further damaged relations. ${ }^{22}$ As a result of these difficulties, Turkey has been keen to build bridges with other actors, and Chinese direct investment in Turkey has increased significantly, with Beijing looking to double this to USD 6 bn by $2021 .{ }^{23}$ China sees Turkey as a useful means of diversifying its overland rail routes to European markets, which could make Turkey an important transit country for its goods. As a result, Turkey and China have worked together to align President Erdogan's 'Middle Corridor' infrastructure strategy with China's BRI. Turkey's Middle Corridor initiative aims to create a belt of prosperity in the eastern part of Turkey, encourage Chinese investment, allow Turkey to become a hub for Chinese-European trade and diversify Ankara's energy supplies. ${ }^{24}$ The damaging effect of the pandemic on the Turkish economy is also likely to further increase Ankara's engagement with China. ${ }^{25}$

China is likely to become an even more important actor in the BSR

As has been discussed in the previous section, while the level of China's investment in the Black Sea varies, Beijing has increased its economic presence in the region. This looks set to continue in the future. One important barometer of maritime economic activity is global freight demand. PreCOVID-19 estimates suggested that global freight demand would triple by 2050, with ships expected to carry more than three quarters of all goods. Maritime freight transport would grow at an estimated rate of 3.6 per cent through to 2050 and this would lead to a near tripling of maritime trade

21 Steven A. Cook, 'Neither friend nor Foe: The Future of US-Turkey Relations', Council on Foreign Relations Press, November 2018.

22 Jim Zanotti et al., 'Turkey: Background and US Relations in Brief', Congressional Research Service, 7 April 2020.

23 'China increased foreign direct investments into Turkey', Global Policy and Analysis Think Tank, 2019.

24 Barçın Yinanç 'Silk Road train 'first step towards a game changer', Hurriyet News, 11 November 2019.

25 Laura Pitel, 'Turkey's economy suffers historic contraction in second quarter', The Financial Times, 31 August 2020. 
volumes. ${ }^{26}$ These optimistic forecasts were a key reason for China's interests in the BSR, in particular in its ports and infrastructure, as discussed above. While the COVID-19 pandemic has called into question the veracity of these predictions, there were signs of a partial recovery of maritime trade in the third quarter of 2020 and a strong indication that shipping traffic will pick up further towards the end of the year. ${ }^{27}$ Recent data has also shown that global containerised freight levels are only marginally below comparative figures last year, suggesting that we are likely to see a return to pre-COVID levels in the BSR in the near future. ${ }^{28}$

The continuation of China's investment in the BSR as part of the BRI will obviously be dependent on whether the Chinese economy can bounce back after the pandemic. Demand for exports from China has slowed internationally as other countries have gone into recession, and so consumption, which is the most sustainable part of Chinese growth, remains low. ${ }^{29}$ China's recovery does, however, look promising. The IMF forecasts China's growth at 1.2 per cent in 2020 and above 5 per cent a year between 2021 and 2025-well ahead of any other major economy. ${ }^{30}$ China has been the first major economy to return to growth since the pandemic.

Maritime traffic in the Black Sea will also be facilitated by the building by the Turkish government of the Istanbul Canal, a project due to be completed by 2025 . The $45 \mathrm{~km}$ canal, an artificial sea-level waterway, will be built connecting the Black Sea and the Mediterranean in Istanbul's Kucukcekmece-Sazlidere-Durusu corridor and is projected to have a transit capacity of 160 vessels a day; similar in volume to the Bosporus. ${ }^{31}$ The new canal will also make the transit into and out of the Black Sea considerably easier and quicker. The Turkish government has banned the night passage from the Bosporus of tankers longer than 200 metres, which has increased the waiting times for ships on either side of the strait. With traffic predicted to hit 86,000 ships by 2070 , the new canal will prove invaluable in in-

26 'Global freight demand to triple by 2050', The Maritime Executive, 11 March 2020.

27 Jan Hoffman et al., 'Navigating through the coronavirus crisis and uncertainty: How maritime transport date can help', UNCTAD Article 60, 7 September 2020.

28 Linton Nightingale, 'Container Volumes edge up to recover lost ground', Lloyds List Maritime Intelligence, 7 September 2020.

29 Keith Bradsher, 'China's Economy Rebounds From Coronavirus, but Shares Fall', The New York Times, 31 August 2020.

30 Sun Yu and Yuan Yang 'Why China's economic recovery from coronavirus is widening the wealth gap', The Financial Times, 18 August 2020.

31 'Transportation minister unveils final 45-kilometer route of Kanal Istanbul project', Daily Sabah, 15 January 2018. 
creasing trade flow in the BSR. ${ }^{32}$ In February 2020, the Turkish Transport and Infrastructure Minister, Cahit Turhan, confirmed that a number of countries, including China, were interested in this project. ${ }^{33} \mathrm{~A}$ month earlier, the Turkish Presidential Communications Director, Fahrettin Altun, reinforced suspicions of Beijing's interest in the canal when he tweeted a video about the Istanbul canal project in Chinese. ${ }^{34}$ The new canal could therefore attract not only further investment in vital infrastructure in the BSR by China, but could also increase access in and out of the Black Sea, reduce waiting times and so ultimately also reduce the costs of shipping in the region; something that Beijing will be keen to exploit.

Despite Chinese interests, there is uncertainty, however, as to whether the Turkish government will apply the 1936 Montreux Convention to the new canal and what this would mean for the balance of military power in the region. Under the Montreux Convention, access to the Black Sea for military ships is unrestricted for the littoral states, whereas the Convention limits the tonnage, duration and frequency of visits for all other navies. The Turkish government has yet to determine whether it will set different rules for military maritime traffic on the new canal. ${ }^{35}$ If military maritime traffic using the new canal was not bound by the Montreux Convention, it could potentially alter the maritime balance of power in the BSR.

\section{Opportunities and challenges for NATO in the BSR}

Growing Chinese interest in the BSR poses a number of potential maritime security challenges for NATO that will need to be considered in a revised edition of the AMS. Perhaps the most important issue will be the extent to which China could use the deep-sea ports, tunnels, bridges, roads and critical infrastructure it has been developing to damage NATO's interests and footprint in the region. ${ }^{36}$ There are legitimate concerns that

32 Frank Jacobs, 'Why Erdogan wants to turn Istanbul into an island', Big Think, 14 September 2020.

33 'Turkish President's Canal Project interests Chinese Investors', Belt and Road News, 3 December 2019.

34 'Turkish communication director's Chinese tweets on Canal Istanbul raises eyebrow', BBC Monitoring, 7 January 2020.

35 Mehmet Emin Birpinar, 'Maritime developments make Kanal Istanbul necessary', Daily Sabah, 3 September 2020.

36 Stefanie Babst, 'The time is ripe for NATO to consider a dual-track approach to China', European Leadership Network, 7 September 2020. 
Chinese investment in ports and rail infrastructure in the Black Sea Region could potentially complicate NATO's mobility into and out of the region. ${ }^{37}$ For instance, Chinese control over Bulgarian and Georgian ports in the Black Sea could decrease the willingness of NATO members to move military forces-including sensitive technology—through the ports and surrounding networks. This could affect planning, resulting in fewer military exercises in the BSR, decreasing NATO's ability to defend the region in the future. ${ }^{38} \mathrm{~A}$ Chinese debt crisis in the BSR, particularly in light of the pandemic, could also have security implications for NATO as Beijing could seize assets such as ports or infrastructure in lieu of debt repayments by littoral states and could thereby also limit NATO's access and potential presence in the BSR.

A second challenge to NATO's security and that of its members and partners in the BSR is the risk that some of the smaller littoral states could get caught up in the ongoing great power competition between the US and China. While the election of a new President, Joe Biden, is likely to see the development of a steadier and more coherent China policy than under the previous administration, the competitive relationship between Washington and Beijing is likely to continue in the future given the bipartisan view within the US that China is its most serious strategic competitor. ${ }^{39}$ As a result, the new US administration is as likely as the previous administration to put pressure on NATO partners Ukraine and Georgia, as well as NATO members such as Bulgaria, to limit their cooperation with China, particularly on issues relating to security and technological issues. This will put these littoral states in the difficult position of having to try to reconcile often competing economic and political interests, and perhaps of even having to make starker choices between East and West.

Lastly, an additional challenge posed by China's growing interests in the BSR is that Moscow and Beijing might engage in systematic strategic cooperation in the region, blocking, or at least complicating, NATO's active engagement. Despite widespread scepticism about the longevity of the special relationship between Russia and China, there is evidence of cooperation and coordination between the two powers. ${ }^{40}$ Both consider Eurasia

37 Christopher Woody, 'NATO is finally talking about China, and there are 3 big problems', Business Insider India, 5 December 2019.

38 Lauren Speranza, 'China Is NATO's New Problem', Atlantic Council, 8 July 2020.

39 Dan Baer, 'America under Biden won't go soft on China', Carnegie Endowment for International Peace, 6 November 2020.

40 Nadege Rolland, 'A China-Russia condominium over Eurasia', Survival, January 2019, 7-22. 
their strategic backyard, share similar concerns about political stability and security in the area, and have launched ambitious initiatives to strengthen their influence over the region. China's strategy in Eurasia, which has been to foster cooperation and persuade the Kremlin that China's Eurasian ambitions actually support Russian goals, has focused on highlighting common political, economic and security interests and, perhaps most importantly of all, on ceding Moscow a leadership role in a region that it regards as falling within its sphere of influence. ${ }^{41}$ There is concern, therefore, that this strategic cooperation, or at least deconfliction, between Russia and China in Eurasia could be extended to include the BSR. There are certainly signs of China's sensitivity to Russia's interests in the BSR. For instance, Beijing has been unhelpful on key diplomatic issues critical to Georgian security despite its close relationship with Tbilisi; and China has been silent on Russia's illegal annexation of the Crimea and its support for separatists in the east of Ukraine despite investing heavily in ports and infrastructure in the Sea of Azov, and despite China's general opposition to attempts to challenge principles of state sovereignty. ${ }^{42}$ If China further seeks to extend its influence in the Black Sea, then there is a possibility that it will seek to extend its cooperation with Russia into the area.

However, this future isn't necessarily certain. The expansion of the BRI into the BSR could equally present opportunities for NATO to work more closely with China. As China pushes increasingly into the BSR, Beijing could well be looking for a stable geostrategic environment. Beijing will therefore be keen to promote the status quo and want to avoid creating a challenging maritime environment as this could damage its investments. China's growing influence could therefore act to curtail, or at least restrain, Russia's more destabilising policies and actions in the BSR because these might create a challenging and problematic operating environment for China's Maritime Silk Road. In practical terms, this is likely to mean that China's investments in Mariupol in the Sea of Azov could have a calming effect on tensions between Ukraine and Russia. Russia will want to avoid antagonising a key ally_China—by provoking further maritime conflict and, more importantly, delaying the transit of Chinese cargo through the Kerch Straits. Similarly, China's presence in Georgia could act as a dampener in terms of future clashes between Russia and Georgia over South Ossetia and Abkhazia. While China's engagement in the BSR under

41 ibid. 8.

42 Emil Avdaliani, 'A Chill in Georgia-China Relations', Modern Diplomacy, 3 October 2020. 
the BRI will not radically change Russia's policy towards Georgia or Ukraine, it could serve to limit Russia's freedom of manoeuvre and create a calmer and less challenging maritime environment.

In addition, given China's interests in ensuring the safe transit of its maritime traffic in the BSR, some of the smaller littoral states with good relations with Beijing might look at encouraging China's engagement in maritime security operations in the region. China has demonstrated a commitment to using its naval forces to address international maritime security issues. Since 2008, the Chinese navy has participated in United Nations mandated anti-piracy patrols in and around the Gulf of Aden and Somalia. Indicating the strategic value of protecting Beijing's commercial maritime interests, Chinese policy guidelines also clearly point towards a potential role for the Chinese navy in protecting aspects of the Maritime Silk Road. ${ }^{43}$ Given the expansion of the BRI into the Black Sea, Beijing has a vested interest in working with NATO members and partners in the region to address common maritime security challenges such as piracy, pollution and terrorism. Chinese naval engagement in the Black Sea has been very limited so far. In 2012, the Chinese navy engaged in a number of goodwill visits to Sevastopol, Istanbul, Varna and Constanta after finishing its deployment in the Gulf of Aden on anti-piracy operations. ${ }^{44}$ Since then, two Chinese warships have taken part in Victory Day celebrations in Novorossiysk in the Black Sea in 2015. Although this was clearly a sign of the strength and depth of its security relationship with Moscow, it does indicate that China recognises that the Black Sea matters. Although the BSR is clearly not a top priority for the Chinese navy, encouraging goodwill visits, as well its engagement in regional maritime security operations, is clearly also in NATO's interests. While Chinese naval engagement in the Black Sea could pose security issues for NATO, the potential benefits of encouraging Chinese engagement in regional maritime security operations could outweigh the challenges.

43 Veerle Nouwens, 'Who Guards the 'Maritime Silk Road', War on the Rocks, 24 June 2020.

44 Joshua Kucera, 'Chinese warships in Black Sea for Russian Victory Day celebrations', Eurasianews, 7 May 2015. 


\section{Conclusion}

China has become an important actor in the Black Sea, and developments in the region mean that its influence is likely to continue to grow in the future. The challenges this poses for NATO members and partners currently outweigh the opportunities. These challenges include the security implications of China's potential ability to deny NATO members access to vital infrastructure, including ports in the region, the return of great power competition to the Black Sea and the extension of Sino-Russian strategic cooperation into the region. The opportunities of the rise of China in the BS for NATO are more limited. These include the potentially stabilising effects of Chinese economic interests on the region, in particular on encouraging Russian restraint, and the potential for Beijing's participation in maritime security operations. These challenges and potential opportunities will therefore need to be reflected in NATO's AMS.

\section{Works cited}

Avdaliani, Emil, 'A Chill in Georgia-China Relations', Modern Diplomacy, 3 October 2020, https://moderndiplomacy.eu/2020/10/23/a-chill-in-georgia-china-relati ons/.

Avdaliani, Emil, 'China set to increase its influence in Georgia', Georgia Today, 30 May 2019, http://georgiatoday.ge/news/15824/China-Set-to-Increase-its-Influence -in-Georgia.

'AIIB allocates $\$ 100$ million fund to Georgia for COVID-19', Belt and Road News, 23 May 2020, https://www.beltandroad.news/business/finance/aiib-allocates-100million-fund-to-georgia-for-covid-19/.

'APM Terminals unveils expansion project for Georgia's Poti Sea Port', SAFETY4SEA, 5 February 2020, https://safety4sea.com/apm-terminals-unveils-expansi on-project-for-georgias-poti-sea-port/.

Baer, Dan, 'America under Biden won't go soft on China', Carnegie Endowment for International Peace, 6 November 2020, https://carnegieendowment.org/2020/11/0 6/america-under-biden-won-t-go-soft-on-china-pub-83164.

'Bulgaria agrees four-motorway deal with government of China', Global Construction Review, 9 July 2018, https://www.globalconstructionreview.com/news/bulga ria-agrees-four-motorway-deal-government-chin/.

'China increased foreign direct investments into Turkey', Global Policy and Analysis Think Tank, 2019.

'China secures Bulgaria foothold', Port Strategy, 18 April 2019, https://www.portstra tegy.com/news101/world/europe/cmec-secures-us $\$ 135.5 \mathrm{~m}$-bulgarian-port-projec t. 
'China to Invest EUR $20 \mathrm{M}$ in Bulgaria's Burgas Port to Facilitate Trade with Europe', Novinite.com. 6 May 2016, https:/www.novinite.com/articles/174354/China +to+Invest+EUR+20+M+in+Bulgaria $\%$ E2\% $\% 0 \% 99 s+$ Burgas+Port+to+Facilitate + T rade+with+Europe.

'Chinese company signs deal to upgrade Ukraine's Black Sea ports', Xinhua, 7 April 2018, http://www.xinhuanet.com/english/2018-04/07/c_137092619.htm.

Babst, Stefanie, 'The time is ripe for NATO to consider a dual-track approach to China', European Leadership Network, 7 September 2020, https:/www.europeanl eadershipnetwork.org/commentary/the-time-is-ripe-for-nato-to-consider-a-dual-tr ack-strategy-towards-china/.

Birpinar, Mehmet Emin, 'Maritime developments make Kanal Istanbul necessary', Daily Sabah, 3 September 2020, https:/www.dailysabah.com/opinion/op-ed/mar itime-developments-make-kanal-istanbul-necessary.

Bradsher, Keith, 'China's Economy Rebounds From Coronavirus, but Shares Fall', The New York Times, 31 August 2020.

Brzozowski, Alexandra, 'China 'not an enemy' but NATO must face growing role, NATO chief says', Euractiv, 8 June 2020, https://www.euractiv.com/section/defe nce-and-security/news/china-not-an-enemy-but-nato-must-face-growing-role-nato -chief-says/.

Cook, Steven A., 'Neither friend nor Foe: The Future of US-Turkey Relations', Council on Foreign Relations Press, Council Special Report No. 82, November 2018.

Daly, John C. K., 'China and Georgia Deepen Transit Cooperation', Eurasian Daily Monitor, 15/63, 23 April 2018.

Datskevych, Natalia, 'It's official: China is Ukraine's largest trading partner', Kyiv Post, 27 September 2019, https://www.kyivpost.com/business/its-official-china-isukraines-largest-trading-partner.html.

Gerasymchuk, Sergiy and Potitta, Yurri, 'Ukraine-China after 2014: a new chapter in the relationship', Friedrich Ebert Stiftung, Kyiv, 26 September 2018.

'Global freight demand to triple by 2050', The Maritime Executive, 11 March 2020, https:/www.maritime-executive.com/article/global-freight-demand-to-triple-by-2 050 .

Hoffman, Jan, Benamara, Hassiba, Hopp, Daniel, Rodriguez, Luisa, 'Navigating through the coronavirus crisis and uncertainty: How maritime transport date can help', UNCTAD Article 60, 7 September 2020.

'IMF seeks Georgia's economy contracting by 5\% in 2020', Reuters, 16 September 2020.

'Interview: Belt and Road Initiative could put Bulgaria on global logistics map: expert', Xinhua, 27 June 2018, http://www.xinhuanet.com/english/2018-06/27/c_13 7284824.htm.

Jacobs, Frank, 'Why Erdogan wants to turn Istanbul into an island', Big Think, 14 September 2020, https://bigthink.com/strange-maps/kanal-istanbul. 
Kucera, Joshua, 'Chinese warships in Black Sea for Russian Victory Day celebrations', Eurasianews, 7 May 2015, https://eurasianet.org/chinese-warships-in-blacksea-for-russian-victory-day-celebrations.

Larsen, Joseph, 'Georgia: The Black Sea Hub for China's 'Belt and Road', The Diplomat. 3 May 2017; https://thediplomat.com/2017/05/georgia-the-black-sea-hub-for -chinas-belt-and-road/.

Maçães, Bruno, Belt and Road, A Chinese World Order, (C. Hurst \& Co, 2018).

Nightingale, Linton, 'Container Volumes edge up to recover lost ground', Lloyds List Maritime Intelligence, 7 September 2020.

Nouwens, Veerle, 'Who Guards the 'Maritime Silk Road', War on the Rocks, 24 June 2020, https://warontherocks.com/2020/06/who-guards-the-maritime-silk-road/.

Pitel, Laura, 'Turkey's economy suffers historic contraction in second quarter', The Financial Times, 31 August 2020.

Query, Alexander, 'China to invest over $\$ 50 \mathrm{~m}$ in port city of Mariupol', Kyiv Post, 29 October 2019, https://www.kyivpost.com/business/china-to-invest-over-50-mil lion-in-port-city-of-mariupol.html.

Ringsmore, Jens and Rynning, Sten, 'China brought NATO closer together', War on the Rocks, 5 Feb 2020, https://warontherocks.com/2020/02/china-brought-nato -closer-together/.

Rolland, Nadege, 'A China-Russia condominium over Eurasia', Survival, vol. 61, January 2019, 7-22.

Speranza, Lauren, 'China Is NATO's New Problem', Atlantic Council, 8 July 2020, https://foreignpolicy.com/2020/07/08/china-nato-hybrid-threats-europe-cyber/.

Topuria, Revaz, 'Georgia: The Key to China's 'Belt and Road', The Diplomat, 28 April 2016, https://thediplomat.com/2016/04/georgia-the-key-to-chinas-belt-and$\mathrm{road} /$.

'Transportation minister unveils final 45-kilometer route of Kanal Istanbul project', Daily Sabah, 15 January 2018, https:/www.dailysabah.com/business/2018/01/15/ transportation-minister-unveils-final-45-kilometer-route-of-kanal-istanbul-projec t.

'Turkish communication director's Chinese tweets on Canal Istanbul raises eyebrow', BBC Monitoring, 7 January 2020.

'Turkish President's Canal Project interests Chinese Investors', Belt and Road News, 3 December 2019, https://www.beltandroad.news/business/development/turkish -presidents-canal-project-interest-chinese-companies/.

Woody, Christopher, 'NATO is finally talking about China and there are 3 big problems it has to address', Business Insider India, 5 December 2019; https://www .businessinsider.in/defense/news/nato-is-finally-talking-about-china-and-there-are -3-big-problems-it-has-to-address/articleshow/72392083.cms.

Yinanç, Barçın, 'Silk Road train 'first step towards a game changer', Hurriyet News, 11 November 2019, https://www.hurriyetdailynews.com/silk-road-train-first-step -towards-a-game-changer-148533.

Yu, Sun and Yang, Yuan, 'Why China's economic recovery from coronavirus is widening the wealth gap', The Financial Times, 18 August 2020. 
Zanotti, Jim and Thomas, Clayton, 'Turkey: Background and US Relations in Brief, Congressional Research Service, 7 April 2020, https://fas.org/sgp/crs/mideast/ R44000.pdf. 